\section{Pacific Northwest}

National Laboratory

Operated by Battelle for the

U.S. Department of Energy

\title{
India's Worsening Uranium Shortage
}

\author{
M.M. Curtis
}

January 2007

Prepared for the U.S. Department of Energy under Contract DE-AC05-76RL01830

Pacific Northwest National Laboratory

Richland, Washington 99354 


\title{
DISCLAIMER
}

This report was prepared as an account of work sponsored by an agency of the United States Government. Neither the United States Government nor any agency thereof, nor Battelle Memorial Institute, nor any of their employees, makes any warranty, express or implied, or assumes any legal liability or responsibility for the accuracy, completeness, or usefulness of any information, apparatus, product, or process disclosed, or represents that its use would not infringe privately owned rights. Reference herein to any specific commercial product, process, or service by trade name, trademark, manufacturer, or otherwise does not necessarily constitute or imply its endorsement, recommendation, or favoring by the United States Government or any agency thereof, or Battelle Memorial Institute. The views and opinions of authors expressed herein do not necessarily state or reflect those of the United States Government or any agency thereof.

\author{
PACIFIC NORTHWEST NATIONAL LABORATORY \\ operated by \\ BATTELLE \\ for the \\ UNITED STATES DEPARTMENT OF ENERGY \\ under Contract DE-AC05-76RL01830
}

Printed in the United States of America

Available to DOE and DOE contractors from the

Office of Scientific and Technical Information,

P.O. Box 62, Oak Ridge, TN 37831-0062;

ph: (865) 576-8401

fax: (865) 576-5728

email: reports@adonis.osti.gov

\author{
Available to the public from the National Technical Information Service, \\ U.S. Department of Commerce, 5285 Port Royal Rd., Springfield, VA 22161 \\ ph: (800) $553-6847$ \\ fax: (703) 605-6900 \\ email: orders@ntis.fedworld.gov \\ online ordering: http://www.ntis.gov/ordering.htm
}

This document was printed on recycled paper.

$(9 / 2003)$ 


\section{India's Worsening Uranium Shortage}

M. M. Curtis

January 2007

Prepared for

the U.S. Department of Energy

under Contract DE-AC05-76RL01830

Pacific Northwest National Laboratory

Richland, Washington 99354 


\section{Contents}

\begin{tabular}{|c|c|}
\hline 1.0 & troduction.. \\
\hline 2.0 & ranium Supply \\
\hline 2.1 & Mine Output . \\
\hline 2.1.1 & Jaduguda Mill.... \\
\hline 2.1 .2 & Singhbhum East District, Jharkand (proposed).. \\
\hline 2.1 .3 & Lambapur-Peddagattu in Nalgonda District, Andrhra-Pradesh State (proposed). \\
\hline 2.1 .4 & Domiasiat in Meghalaya State (proposed) ................... \\
\hline & . \\
\hline & $\ldots \ldots$ \\
\hline & Uran \\
\hline & Conclusion ................ \\
\hline & fferences ...... \\
\hline
\end{tabular}

\section{Figures}

Figure 1. Uranium Mines_C Current and Proposed .................................................................................. 2

\section{Tables}

Table 1. Mines in the Singhbhum East District, Jharkand (operating) …..................................................... 3

Table 2. Mines in the Singhbhum East District, Jharkand (under development) ........................................... 3

Table 3. PHWR Ratings for India’s Operating Plants................................................................................. 6 


\subsection{Introduction}

As a result of the Nuclear Supplier's Group (NSG) restrictions, India cannot import the natural uranium required to fuel its Pressurized Heavy Water Reactors (PHWRs); consequently, it is forced to rely on the expediency of domestic uranium production. However, domestic production from mines and byproduct sources has not kept pace with demand from commercial reactors. This shortage has been officially confirmed by the Indian Planning Commission's Mid-Term Appraisal of the country's current Five Year Plan. The report stresses that as a result of the uranium shortage, Indian PHWR load factors have been continually decreasing. ${ }^{1}$ The Uranium Corporation of India Ltd (UCIL) operates a number of underground mines in the Singhbhum Shear Zone of Jharkhand, and all the ore is processed at a single mill in Jaduguda. UCIL is attempting to aggrandize operations by establishing new mines and mills in other states, but the requisite permit-gathering and development time will defer production until at least 2009. A significant portion of India's uranium comes from byproduct sources, but a number of these are derived from accumulated stores that are nearing exhaustion.

A current maximum estimate of indigenous uranium production is 430t/yr (230t from mines and 200t from byproduct sources); whereas, the current uranium requirement for Indian PHWRs is 455t/yr (depending on plant capacity factor). This deficit is exacerbated by the additional requirements of the Indian weapons program. Present power generation capacity of Indian nuclear plants is 4350 MWe. The power generation target set by the Indian Department of Atomic Energy (DAE) is 20,000 MWe by the year 2020. It is expected that around half of this total will be provided by PHWRs using indigenously supplied uranium with the bulk of the remainder provided by breeder reactors or pressurized water reactors using imported low-enriched uranium.

\subsection{Uranium Supply}

\subsection{Mine Output}

Both UCIL and its exploratory arm, the Atomic Minerals Directorate for Exploration and Research (AMD) are Public Sector Enterprises that are owned and operated by the DAE. DAE policy is that uranium reserve estimates and mill output are proprietary; hence, reporting is typically conveyed with a disclaimer. For example, AMD's estimate of reasonably assured uranium reserves is 64kt with 30kt of additional resources, but the figures are reported without an associated cost of extraction, and without it, the reserve values are meaningless. ${ }^{2}$

India's present and potential mining areas are illustrated in Figure 1. Currently operating mines are in the Singhbuhm East belt. They include Jaduguda, Narwapahar, Bhatin, and Turamdih. 


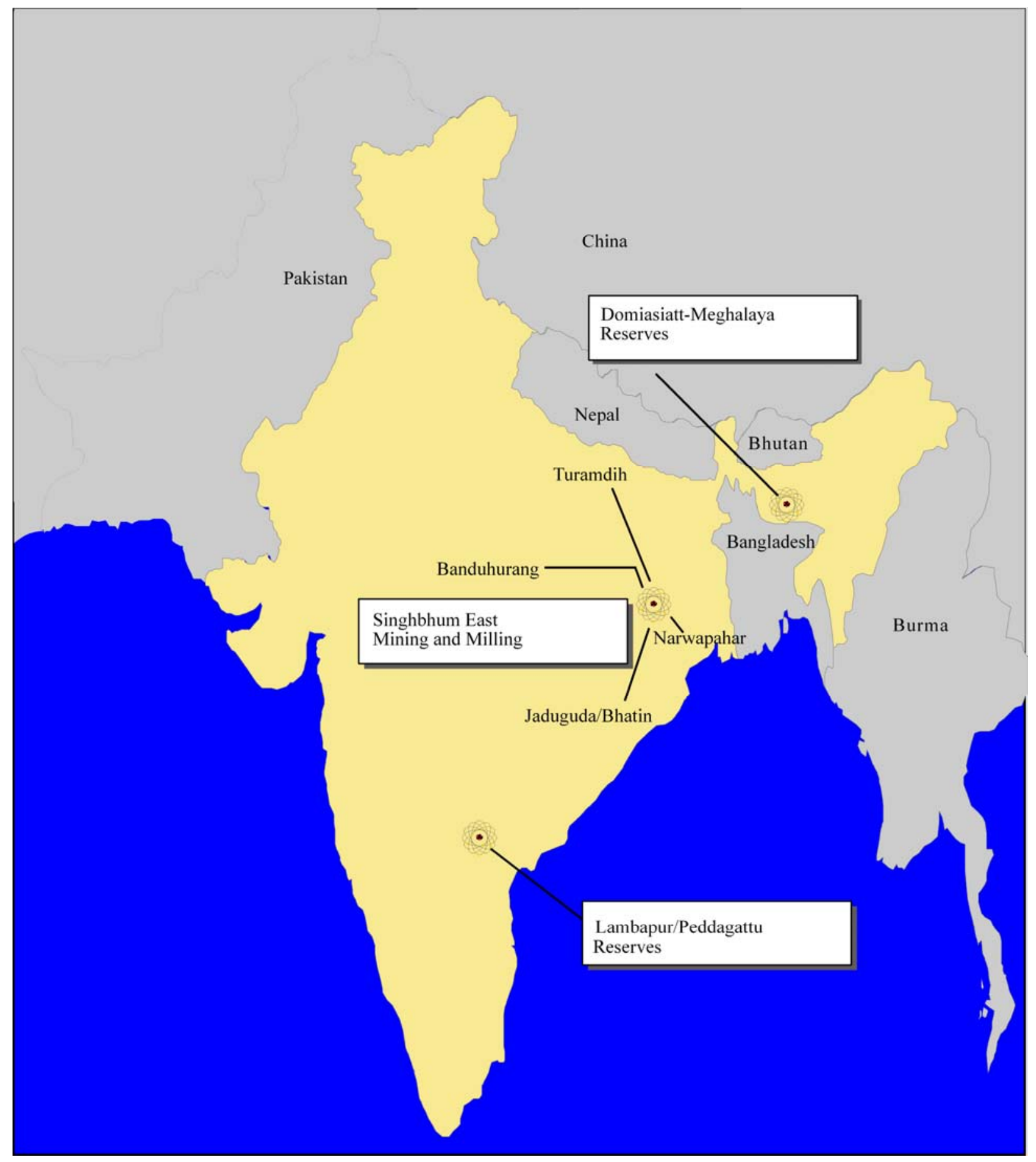

Figure 1. Uranium Mines-Current and Proposed

Both present and prospective uranium production is assessed here in terms of its source, starting with the operating mines in the Singhbhum East District (Table 1). Ore from these mines is of low assay 0.03-0.06\% $\mathrm{U}_{3} \mathrm{O}_{8}$. Such values hardly constitute ore even at today's inflated uranium price ( $\$ 72 / \mathrm{lb} \mathrm{U}_{3} \mathrm{O}_{8}$ January, 2007). By comparison, Cameco’s Cigar Lake deposit has 1.2 million tons of ore that is $14 \% \mathrm{U}_{3} \mathrm{O}_{8}$. 
Table 1. Mines in the Singhbhum East District, Jharkand (operating)

\begin{tabular}{|l|l|l|l|}
\hline \multicolumn{1}{|c|}{ Mine } & \multicolumn{1}{|c|}{ Capacity (ore) $^{\mathbf{3}}$} & \multicolumn{1}{c|}{ Associated Mill } & \multicolumn{1}{c|}{ Type } \\
\hline Jaduguda & $600 t /$ day & Jaduguda & $\begin{array}{l}\text { Underground. An exploratory shaft now extends } \\
\text { to 900m. The increased depth exacerbates the cost } \\
\text { of haulage and ventilation. }\end{array}$ \\
\hline Bhatin & 130 t/day & Jaduguda & Underground \\
\hline Narwapahar & $1,000 t /$ day & Jaduguda & Underground \\
\hline Turamdih & $550 t /$ day & $\begin{array}{l}\text { Jaduguda (presently) but } \\
\text { ore will be processed at } \\
\text { Turamdih mill when it } \\
\text { opens }\end{array}$ & Underground \\
\hline
\end{tabular}

\subsubsection{Jaduguda Mill}

The Jaduguda mill in the Singhbhum East District receives ore from the Jaduguda, Bhatin, and Narwapahar mines, and soon it will process ore from the Bagjata mine. The mill processes 2,100t of dry ore per day with an average recovery of $80 \%$. There are no plans for future expansion of this mill.

The 2005 Uranium Redbook gives a nominal output of 175t/yr U from the Jaduguda mill. ${ }^{4}$ Another estimate gives 200t/yr as $\mathrm{U}_{3} \mathrm{O}_{8}$ equivalent, although actual output is in the form of magnesium diuranate. ${ }^{5}$ Other sources reference a value of 220t/yr of yellowcake. The World Nuclear Association (WNA) gives a more generous estimate of 230t/yr of uranium, a value that has remained constant from 2002-2005. ${ }^{6}$ The estimate from WNA, the highest, will be considered for current mill output since it will be shown that even if this value is assumed, there still exists a present shortage.

\subsubsection{Singhbhum East District, Jharkand (proposed)}

The East Singhbhum district is the only area where mine development is actually being realized. Operating mines are being deepened as new ones undergo development. The three mines in Table 2 are in the vicinity of the four currently operating.

Table 2. Mines in the Singhbhum East District, Jharkand (under development)

\begin{tabular}{|l|l|l|l|}
\hline Proposed Mine & \multicolumn{1}{|c|}{$\begin{array}{c}\text { Anticipated } \\
\text { Capacity (ore) }\end{array}$} & Associated Mill & \multicolumn{1}{c|}{ Type } \\
\hline Bagjata & $500 t /$ day & Jaduguda & $\begin{array}{l}\text { Underground } \\
\text { Bagjata was closed in 1992 when DAE funding was cut. } \\
\text { Development recommenced in January 2004. }\end{array}$ \\
\hline Banduhurang & $2250 \mathrm{t} /$ day & Turamdih & $\begin{array}{l}\text { Open pit. Removal of overburden in progress. Expected to } \\
\text { begin operations shortly. }\end{array}$ \\
\hline Mohuldih & $1250 \mathrm{t} /$ day & $\begin{array}{l}\text { Turamdih (after } \\
\text { mill expansion) }\end{array}$ & Underground/open pit \\
\hline
\end{tabular}


The Turamdih mill, which is still under construction, will receive ores from the Banduhurang, Turamdih and Mohuldih mines. It is expected to process 3,000t/day of dry ore with an average recovery of $80 \%$. Mill output is expected to be 190t/yr U. Lacking this mill, the Banduhurang mine will have no process outlet, despite the fact that development work on the mine should be completed by the end of 2006.

\subsubsection{Lambapur-Peddagattu in Nalgonda District, Andrhra-Pradesh State (proposed)}

Two underground mines are planned for Peddagattu, and an underground and open-pit mine are envisioned for

Lambapur. An associated mill is being proposed for construction at Seripally, $50 \mathrm{~km}$ away. ${ }^{8}$ For years the Andhra-Pradesh local authorities have frustrated UCIL by refusing to grant a No-Objection-Certificate that would permit the commencement of development activities. Central Government permission was granted for this project in April 2006, but State permission is still lacking. ${ }^{9}$

\subsubsection{Domiasiat in Meghalaya State (proposed)}

Meghalaya contains a deposit of higher-grade ore. It is located in the Northeast on the Bangladesh border. It is a shallow deposit that is expected to accommodate two open-pit mines and an associated mill. The area is one of the rainiest on earth and is inaccessible for half the year. UCIL cannot begin development without permits and the Meghalayan local government has taken no action on their application for years.

In-situ leaching is not envisioned for application at this site since the geology is not amenable to it.

\subsection{Byproduct Uranium}

India may be obtaining nearly half its uranium from secondary sources. Historically these have included copper tailings, phosphate-bearing rock, monazite, thorium hydroxide (an intermediate monazite processing product), and various uranium-bearing residues. ${ }^{10,11} 1213$

- $\quad$ Phosphatic rock is the raw material for all phosphate fertilizers, and India imports over 4 million tons/yr of it. Uranium concentration in phosphatic rock ranges from 3-400 ppm, with the elevated portion found in rocks of sedimentary origin-such as those from Morocco and Jordan. When dissolved in sulfuric acid, they yield a wet phosphoric acid containing 0.1-0.2 g/l $\mathrm{U}_{3} \mathrm{O}_{8}$. Indian Rare Earths Ltd. (IREL) has recently declared the objective of becoming a substantial supplier of uranium from secondary [phosphate] sources. Although presently in the pilot stage, one reference estimated uranium recovery from phosphates could soon be $\sim 140 \mathrm{t} / \mathrm{yr} \mathrm{U}$.

- Although IREL is no longer processing monazite sands for thorium, an accumulated 33,000t of impure thorium hydroxide concentrate will be used to produce sodium diuranate $\left(\sim 30 \mathrm{t} / \mathrm{year} \mathrm{U}_{3} \mathrm{O}_{8}\right.$ equivalent) until the source is exhausted around 2009.

- Uranium residues from imported tantalite/columbite ore provides about 30t/yr of uranium yearly.

- Formerly about 30t of uranium was derived annually from several Hindustan Copper Corp. mines, but these mines are now exhausted and abandoned.

It appears that India could soon be producing as much as 200t/yr U from byproduct sources. Although some of the sources are close to exhaustion, IREL hopes to balance their loss with greater recovery from phosphates. 


\subsection{Imports}

India is relying on indigenous uranium for the bulk of its nuclear program with the exception of the LEU reactors at Tarapur, which have received fuel from Russia as recently as 2006. NSG restrictions would have to be modified to provide unhindered importation of uranium. Beginning in May 2006, senior Indian diplomats speculated on how Australia might be induced to change its export restrictions to permit Canberra to sell yellowcake to India. The Australians later ruled out the possibility since they have never sold uranium to a nonNPT country and their foreign spokesman, Alexander Downer, is on record as saying that now is not the time to make exceptions. ${ }^{14}$

\subsection{Uranium Demand}

The indigenous uranium shortage has had an impact on Indian commercial power production. Plant capacity factors have dropped from $73 \%$ in 2003, to 68\% in 2004, 65\% in 2005, and 53\%.through August 2006. ${ }^{1}$ Only one reactor unit, Rajasthan-2, was operating with a capacity factor over $73 \%$ in $2006 .{ }^{15}$

In estimating the current uranium demand of India's 14 PHWRs, it was assumed that these plants (like most PHWRs worldwide) will operate at an average capacity factor of at least $70 \%$ if adequate supplies of uranium are made available. Fuel burnup is low-typically 6,700 MWD $/ \mathrm{t}^{16}$ and plant efficiency is about $\sim 30 \%$. Thermal power ratings (Table 3) are from Nuclear Power Corporation of India Ltd. (NPCIL). Using these values, the minimum annual uranium demand in tons of heavy metal (tHM) is:

$$
\frac{(3580 M W e)(365 d / y r)(0.70 \text { capacity })}{(0.30 e f f i c i e n c y)(6700 M W D / t)}=455 \text { tHM Uranium }
$$

The use of MOX fuel has been proposed for use in a portion of PHWR cores, but this would affect the control and safety of the plant to a greater degree than in a PWR. ${ }^{17}$

1. The last figure includes only PHWRs. It is the weighted average of all these units through 2006. Figures from the previous years include Tarapur1\&2. With these plants factored in, the capacity factor through August '06 would be $54.3 \%$. 
Table 3. PHWR Ratings for India’s Operating Plants

\begin{tabular}{|l|c|}
\hline \multicolumn{1}{|c|}{ Unit } & ${\text { Rating } \mathbf{M W e}^{\mathbf{2}}}$ \\
\hline Rajasthan (RAPS-1) & 100 \\
\hline Rajasthan (RAPS-2) & 200 \\
\hline Madras-1 (MAPS-1) & 220 \\
\hline Madras-2 (Maps-2) & 220 \\
\hline Narora-1 (NAPS-1) & 220 \\
\hline Narora-1 (NAPS-2) & 220 \\
\hline Kaprapar (KAPS-1) & 220 \\
\hline Kaprapar (KAPS-2) & 220 \\
\hline Kaiga-1 & 220 \\
\hline Kaiga-2 & 220 \\
\hline Rajasthan (RAPS-3) & 220 \\
\hline Rajasthan (RAPS-4) & 220 \\
\hline Tarapur-4 (TAPS-4) & 540 \\
\hline Tarapur-3 (TAPS-3) & 540 \\
\hline Total & $\mathbf{3 5 8 0}$ \\
\hline
\end{tabular}

\subsection{Conclusion}

It is apparent from the drop in capacity factor and the attempts by the Indian Government to secure new sources of uranium, both domestic and foreign, that indigenous uranium supplies are stretched to the limit. The Bagjata mine may come on line in 2007, but it will be discharging to a mill that is already running at full capacity. Banduhurang may also come on line in 2007, but its ore is designated for a mill that is not yet operating. Realistically, it looks as if indigenous uranium production will not increase until at least 2008 and perhaps 2009 as new mines come on line to feed the Turamdih mill. The hope of getting ore from areas of the country outside the Singhbhum district in the next ten years is slim since there is considerable endemic opposition to mine development.

Uranium demand will certainly increase. India has four more PHWRs under construction, Kaiga 3\&4, and Rajasthan 5\&6. The DAE's goal of generating 9,500 MWe from PHWRs by the year 2020 is entirely unachievable without a three-fold increase in uranium supply. ${ }^{18}$ Indigenous output can only triple if the mines proposed in other States are approved and achieve full production, although presently they are only in the initial stages of exploration. Despite India's efforts, increasing domestic production is a specious solution to the shortage problem since there are no true uranium reserves in the country. To be considered ore, a deposit must have $>0.2 \%$ uranium. India's operating mines are well below this limit, and although their prospective mines are marginally richer, they are fraught with environmental and logistic problems. The long-term solution for India's uranium shortage is imports.

2. NPCIL Values were used. Ratings quoted for Indian Power Plants differ among reference source since a number of plants are operating in a derated condition. Tarapur units 3 and 4 are reported to have a slightly higher burnup value, but the equation above is only a rough approximation. Nuclear Engineering International reports the yearly demand for these 14 reactors at 563tHM, but this presumes a capacity factor of 0.85 . 
Lack of the ability to import uranium, with the exception of some low enriched uranium from various countries for their PWR reactors (based on grandfathered agreements or safety exceptions) has been India's problem for decades. Rather than attempt to secure the right to import a wide-range of nuclear technology, it may be expedient for the Indians to garner NSG support for yellowcake imports only. This would be much easier to effect diplomatically. Lacking imports, India will have to severely curtail their ambitious plans for nuclear expansion. 


\subsection{References}

1. Frontline: Vol. 22 Issue 27 December 31-January 13, 2006, The Hindu (quote from National Capital Territory of Delhi Planning Department)

2. Atomic Minerals Directorate for Exploration and Research: Uranium Investigations, http://www.amd.gov.in/work/uranium.htm October 2006

3. Uranium 2005: Resources, Production and Demand, Organization for Economic Cooperation and Development and the International Atomic Energy Agency 2005 (the Redbook)

4. ibid.

5. Mukherjee TK and H Singh, Indian Rare Earths Ltd. Recovery of Uranium and Thorium from Secondary Sources, 14th Annual INS Conf. 2003

6. http://www.world-nuclear.org/info/inf23.htm (Note this is tons $\mathrm{U}$ not magnesium diurantate or $\mathrm{U}_{3} \mathrm{O}_{8}$ equivalent)

7. DAE to explore deep uranium deposits Kakodkar Press Trust of India / Mumbai, October 30, 2006

8. Hindustan Times, December 22, 2005

9. The Hindu, April 11, 2006

10. Indian Rare Earths Ltd. Mumbai, Mission/Vision \& Objectives http://www.indianrareearths.com/RightInfo.htm 2005

11. Mukherjee TK and H Singh, Indian Rare Earths Ltd. Recovery of Uranium and Thorium from Secondary Sources, 14th Annual INS Conf. 2003

12. ibid.

13. Gupta, CK and H. Singh (BARC), Uranium resource Processing: Secondary Sources, India, from Developments in uranium resources, production, demand and the environment, Proceedings of a technical committee meeting held in Vienna, 15-18 June 1999

14. Australia Rules out Uranium Sale to India, AAP General Newswire, Sydney, October 11, 2006

15. Nucleonics Week Vol. 47 issue 6, 2/9/06, Vol. 46 issue 6, 2/10/05, Vol. 47 issue 41, 10/12/06 (Much higher values are quoted on the NPCIL website)

16. Krishnani, PD, Baltej Singh, Umasankari Kannan, Arvind Kumar, Sadhana Mukerji and R. Srivenkatesan, Studies of Advanced Fuel Cycles in Indian Pressurized Heavy Water Reactors and Advanced Heavy Water Reactor PHYSOR 2004-The Physics of Fuel Cycles and Advanced Nuclear Systems: Global Developments, April 25-29, 2004.

17. ibid.

18. Kakodkar, A, Current and Emerging Dimensions of the Indian Nuclear Energy Programme, India Outlook, Nuclear Energy 2006 